\title{
Evaluation of COVID-19 Cognizance among Pharmacy Students of South India
}

\author{
M. Meganathan, K. Madhana Gopal* and Deepa Kameswari P. \\ Department of Pharmacology, Aarupadai Veedu Medical College and Hospital, Puducherry - 607402, India; \\ drmadhanago@gmail.com
}

\begin{abstract}
Novel Coronavirus spread rapidly across the globe was declared a public health emergency by the World Health Organization. The novelty and uncertainty of the virus make it critical for health authorities to prepare appropriate plans for the treatment as well as prevention of the infection. The present pandemic situation can be better controlled if students get engaged in actions to protect the community and their family health. A web-based cross-sectional survey was conducted among pharmacy students of various colleges in South India. Using Google forms, 30 questions were developed related to knowledge on COVID-19 and distributed among pharmacy students. Simple descriptive statistics were used to analyze the study results. A total of 1058 students participated in the survey. Out of 30 questions, an average score of correct answers given by all the students is $49.3 \pm 19.8 \%$. The study findings demonstrate a gap between knowledge and information regarding the clinical aspects of COVID-19 among Pharmacy students.
\end{abstract}

Keywords: COVID-19, Novel Corona Virus, Online Observational Survey, Pharmacy Students, South India

\section{Introduction}

The novel Coronavirus (2019-nCoV) emerged in Wuhan city, China, at the end of 2019 and has spread worldwide ${ }^{1}$. More than a few weeks, this new disease spread over the globe in a fast movement. At the same time, it was announced as a Public Health Emergency of International Concern on January $30^{\text {th }} 2020$ by the World Health Organization $(\mathrm{WHO})^{2}$.

World Health Organization (WHO) and other Chinese health care authorities worked together and found Novel Corona virus (2019-nCov) and named it as COVID-19. First death reported in China on January $11^{\text {th }} 2020$ and over a while infection has spread from China to other parts of the globe. On January $30^{\text {th }}$, WHO declared this outbreak as a Public Health Emergency of International concern ${ }^{3}$. On February $11^{\text {th }} 2020$, WHO announced a name for the new Corona virus disease: COVID-19 (WHO, 2020c). On
March $11^{\text {th }}$, the WHO declared COVID-19 - a pandemic as by then about 114 countries were affected ${ }^{4}$.

Coronaviruses (CoVs) belong to the order, Nidovirales and the family, Coronaviridae. They are positive-sense single-stranded non-segmented RNA viruses categorized based on their antigenicity into four groups: alpha-, beta-, gamma- and delta-CoVs ${ }^{5-6}$. All four groups primarily infect birds and mammals and impacted detrimentally to the poultry industry ${ }^{?}$. Humans get infected with alphaand beta-CoVs presenting symptoms ranging from common cold seen with 229E and OC43 CoVs to croup, pneumonia and bronchiolitis, seen with NL63 HKU1CoVs, similar to the Severe Acute Respiratory Syndrome (SARS) caused by SARS-CoV and the Middle East Respiratory Syndrome (MERS) caused by MERS-CoV, consecutively, led to virulent infections in humans $s^{10-11}$. In November 2002, the SARS outbreak occurred in Southern China infecting 8,089 people with a case-fatality rate

${ }^{*}$ Author for correspondence 
of $9.6 \%$ across 17 countries $^{12}$. MERS, occurred in 2012 in Saudi Arabia infected 2,506 people with $34.0 \%$ casefatality rate in 21 countries around the globe $e^{\frac{13}{3}}$.

Numerous investigations have announced evaluating the virologic qualities and clinical outcomes of COVID19; nonetheless, less study focused on examining the knowledge, perceived severity and controllability of the COVID-19. India is an epidemic nation and the degree of disease spread is incredible compared to some other nation. Higher information concerning COVID-19 would be related to a lower probability of negative perspectives and conceivably risky practices. Students represent a unique population for assessing Knowledge of COVID-19 as they primarily rely on social media. The present epidemic infection can be better controlled if students get engaged in actions to protect the community and their family health. In this instance, there are fewer studies reported on the knowledge of health care students regarding clinical manifestation, diagnosis, transmission modes, treatment strategies and preventive measures. Our present web-based survey gives a general picture of knowledge of pharmacy students on aspects of COVID-19. The study results of this study to evaluate the knowledge gap on clinical aspects of the COVID-19 in pharmacy students during the COVID-19 epidemic may guide in developing preparedness in this pandemic situations.

\section{Materials and Methods}

\subsection{Study Settings and Design}

This was an online observational, cross-sectional survey carried out in Tamil Nadu state of South India using a snowball sampling technique during April 2020. Total 1059 responses obtained from various pharmacy college students during the study period.

\subsection{Recruitment}

This online survey was conducted among pharmacy students using Google forms and an online semistructured questionnaire developed concerning the COVID-19 pandemic knowledge.

\subsection{Inclusion Criteria}

Pharmacy students of all years willing to participate in the study were included in the survey.

\subsection{Exclusion Criteria}

Participants who had taken less than 5 min to complete the questionnaire were excluded from the analysis because this indicates random clicking. Incorrect sociodemographic details entered were also excluded from our analysis.

\subsection{Preparation of Questionnaires}

The questionnaires in the English language consisting of socio-demographic questions and 30 questions based on knowledge and awareness related to COVID-19 disease in the healthcare setting developed with the aid of the current interim guidance and information for healthcare workers published by the CDC and ICMR ${ }^{14-15}$. The formulated questionnaire draft was prior presented to five physicians to assess validity and reliability. A pilot study was performed by presenting the validated questionnaire to ten pharmacy students to assess the acceptability, clarity and significance. Based on the comments received, certain modifications and refinements were made and the final survey link was developed and distributed among the pharmacy students.

All the students attending web classes were asked for voluntary participation in the survey by answering the Google forms. The sample size obtained was 384 when calculated based on reference population of all pharmacy colleges and assuming 50\% response proportion, 5\% margin error and $95 \%$ confidence level ${ }^{16}$.

The investigators have sent the link of survey questioner and appended consent form through e-mails and various social media networks like Whatsapp, Facebook to lectures in different colleges. Further, they requested to roll out the survey link to as many people as possible. Thus the survey extended from first point contact to many people by forwarding the link. The link auto directed the participants towards questions in the Google form. Initially, the subjects were asked for the willingness to participate in the survey. After the acceptance, they directed to fill the demographics followed by 30 questions with multiple choices to be answered. The collected data was analyzed using descriptive statistics. The mean, standard deviation and proportions were analyzed to estimate the study results by using SPSS version 20 .

The study protocol was prior approved by the Human Ethics Committee of Aarupadai Veedu Medical College and Hospital, Kirumampakkam, Puducherry, Tamil Nadu, India. 


\section{Results}

From the student population of various colleges (n $=268,503), 1058$ students participated in the survey. Overall, 912 students (86.2\%) attended a degree course in B. Pharmacy and PharmD, while the remaining 146 (13.7\%) attended a Masters in Pharmacy course. The main characteristics of students grouped by educational area, gender and age are reported in (Table 1).

From (Table 2), the detailed results on answering the questioner were depicted. Among the respondents, 98.3\% are aware of SARS-CoV-2 virus causing COVID-19 and $52.35 \%$ knows COVID-19 is a single-stranded RNA. $42.6 \%$ answered MERS Corona virus, first identified in Saudi Arabia. 86.4\% assumed COVID-19 enters into the human body through nose, mouth and conjunctiva while $69.7 \%$ have complete knowledge on transmission modes and the window period of the virus is 0-7 days known by only 59.6\%. 61.2\% knows dysgeusia and anosmia as an early symptom of COVID-19 and $43.6 \%$ knows two days to 2 weeks incubation period. Question asking significant risk factor for the development of acute respiratory distress syndrome and death in patients with COVID-19 was answered correctly as elevated D-dimer levels by $30.4 \%$. Real-time reverse transcriptionpolymerase chain reaction (RRT-PCR) assay has been a more accurate diagnostic test in the diagnosis of COVID19 was known by $23.8 \%$. The levels of ferritin raise high in COVID-19 infected patients was known by $21.3 \%$, while $36.2 \%$ answered the ideal SPO2 \% for referral of COVID-19 suspected patients from fever OPD was $90 \%$.
Ground glass appearance was the most common CT chest finding observed in COVID-19 infection patients was known by $52.5 \%$. Nasopharyngeal swab collected from a COVID-19 suspect patient should transport at 2 to $8^{\circ} \mathrm{C}$ was answered by $45.3 \%$. Attack of RBC by COVID19 mimics, the poisoning of carbon monoxide gas was known by $32.8 \%$. The meaning of epidemic was known by $89.7 \%$ participates and BCG vaccine postulated to protect against COVID-19 infection was known by $31.3 \% .71 .5 \%$ know about quarantine and $57.5 \%$ know regarding precaution is most accurate regarding the treatment and prevention of COVID-19. Offering PPE to the patients is not an appropriate measure while transferring a highly suspected COVID-19 patient to isolation ward from fever clinic was known by $28.2 \%$. Median time from onset to clinical recovery for patients with severe or critical COVID-19 disease was approximately 3-6 weeks was answered by $35.1 \%$. The potential mechanism of Chloroquine against SARS-CoV 2 was known by $35.8 \%$. Ivermectin 5000 fold decrease in the viral load within $48 \mathrm{hrs}$ in the in-vitro studies of COVID-19 culture was known by $58.3 \%$. Metformin withheld in the initial stage of COVID-19 infected diabetic patients was known by $66.7 \%$. Norepinephrine is the vasopressor of the first choice in a shocked COVID-19 patient was insured by $42.6 \%$. The most common co-morbidity seen in severely ill COVID-19 patients is hypertension was correctly answered by $29.1 \%$. ARDS is the most common cause of death due to COVID-19 infection was said by $46.7 \%$. Disseminated thrombosis, the most commonly observed post-mortem finding in COVID-19 infected patients was answered by $37.2 \%$.

Table 1. Student characteristics

\begin{tabular}{|l|c|c|c|}
\hline \multicolumn{1}{|c|}{ Variable } & Whole sample n=1058 & B. Pharm/PharmD N=912 & $\begin{array}{c}\text { M.Pharm } \\
\text { N= 146 }\end{array}$ \\
\hline Age Mean \pm SD & $21.8 \pm 2.3$ & $21.2 \pm 1$ & $22.1 \pm 2.8$ \\
\hline Gender n (\%) & $452(42.7 \%)$ & $395(43.3 \%)$ & $59(40.4 \%)$ \\
\hline Male & $606(57.2 \%)$ & $517(56.6 \%)$ & $87(59.5 \%)$ \\
\hline Female & &
\end{tabular}


Table 2. Detailed report on correct answers given by the respondents

\begin{tabular}{|c|c|c|}
\hline Sl.No & Questions & $\%$ of total correct answers \\
\hline 1. & Which virus is responsible for COVID-19 disease? & 98.3 \\
\hline 2. & What type of virus is Coronavirus? & 52.3 \\
\hline 3. & MERS Corona virus was first identified in which country & 42.6 \\
\hline 4. & $\begin{array}{l}\text { Novel Corona virus causing COVID-19 disease enters into a human } \\
\text { host though }\end{array}$ & 86.4 \\
\hline 5. & How does Coronavirus transmit? & 69.7 \\
\hline 6. & What is window period for COVID-19? & 59.6 \\
\hline 7. & What are the early symptoms of COVID-19? & 61.2 \\
\hline 8. & $\begin{array}{l}\text { Which of the following most accurately reflects the estimated } \\
\text { incubation period of COVID-19? }\end{array}$ & 43.6 \\
\hline 9. & $\begin{array}{l}\text { Which of the following is the most commonly reported clinical finding } \\
\text { in patients with COVID-19? }\end{array}$ & 61.0 \\
\hline 10. & $\begin{array}{l}\text { Which of the following has been recognized as a significant risk factor } \\
\text { for the development of acute respiratory distress syndrome and death } \\
\text { in patients with COVID-19? }\end{array}$ & 30.4 \\
\hline 11. & $\begin{array}{l}\text { Of the following, which diagnostic test has been more accurate in the } \\
\text { diagnosis of COVID-19? }\end{array}$ & 23.8 \\
\hline 12. & What is the levels of ferritin in COVID-19 infected patients is? & 21.3 \\
\hline 13. & $\begin{array}{l}\text { What is the ideal SPO2 \% for referral of COVID-19 suspected patients } \\
\text { from fever OPD to special COVID centre is below what level? }\end{array}$ & 36.2 \\
\hline 14. & $\begin{array}{l}\text { What is the most common CT chest finding observed in COVID-19 } \\
\text { infection? }\end{array}$ & 52.5 \\
\hline 15. & $\begin{array}{l}\text { Nasopharyngeal swab collected from a COVID- } 19 \text { suspect patient } \\
\text { should be transported to a laboratory (that takes } 24 \text { hours to reach) in } \\
\text { Viral Transport Medium (VTM) maintaining at what temperature }\end{array}$ & 45.3 \\
\hline 16. & Attack of RBC by COVID-19 mimics, the poisoning of what gas & 32.8 \\
\hline 17. & What is an epidemic disease? & 89.7 \\
\hline 18. & $\begin{array}{l}\text { Which vaccine is postulated to provide protection against COVID-19 } \\
\text { infection? }\end{array}$ & 31.3 \\
\hline 19. & $\begin{array}{l}\text { Separation of individuals who are not yet ill but have been exposed to } \\
\text { COVID-19 and potential to become ill is referred as }\end{array}$ & 71.5 \\
\hline 20. & $\begin{array}{l}\text { What precaution is most accurate regarding the treatment and } \\
\text { prevention of COVID-19? }\end{array}$ & 57.5 \\
\hline 21. & $\begin{array}{l}\text { Which is NOT an appropriate measure while transferring a highly } \\
\text { suspected COVID-19 patient to Isolation Ward from fever clinic in } \\
\text { your hospital? }\end{array}$ & 28.2 \\
\hline 22. & $\begin{array}{l}\text { What is the median time from onset to clinical recovery for patients } \\
\text { with severe or critical COVID-19 disease is approximately? }\end{array}$ & 35.1 \\
\hline 23. & What is the potential mechanism of Chloroquine against SARS-CoV2? & 35.8 \\
\hline 24. & $\begin{array}{l}\text { Which drug showed } 5000 \text { fold decrease in the viral load within } 48 \text { hrs } \\
\text { in the invitro studies of COVID- } 19 \text { culture? }\end{array}$ & 58.3 \\
\hline
\end{tabular}




\begin{tabular}{|l|l|c|}
\hline 25. & $\begin{array}{l}\text { Which of the following drug can be withheld in the initial stage of } \\
\text { COVID-19 infected diabetic patients? }\end{array}$ & 36.7 \\
\hline 26. & $\begin{array}{l}\text { What are the contraindications on usage of Protease inhibitors in } \\
\text { COVID-19 infected patients? }\end{array}$ & 42.6 \\
\hline 27. & $\begin{array}{l}\text { Which of the following is the vasopressor of first choice in a shocked } \\
\text { COVID-19 patient? }\end{array}$ & 29.1 \\
\hline 28. & $\begin{array}{l}\text { What is the most common comorbidity seen in severely ill COVID-19 } \\
\text { patients? }\end{array}$ & 46.7 \\
\hline 29. & What is the most common cause of death due to COVID-19 infection? & 37.2 \\
\hline 30. & $\begin{array}{l}\text { What is the most commonly observed postmortem finding in COVID } \\
\text {-19 infected patients? }\end{array}$ & 49.3 \\
\hline & Mean & 19.8 \\
\hline & Standard deviation & \multicolumn{2}{|c|}{} \\
\hline
\end{tabular}

\section{Discussion}

The present study was to evaluate the degree of knowledge of Indian Pharmacy students about clinical aspects and preventive measures on COVID-19. The findings showed an average level of knowledge in the majority of the students which is consistent with the reports of other studies recently performed among other students $\underline{1-1}-\underline{18}$. Moreover, the sample showed higher female respondents similar as reported in investigations during the COVID19 pandemic ${ }^{19-21}$. Even though we have not investigated the source of information by students, it should be considered that the knowledge was obtained by watching television, web browsing home during lockdown and attending webinars on COVID-19.

Despite the level of education, respondents were not proficient about most COVID-19 variables. The lower degree of COVID-19 knowledge highlights the need to educate the students with accurate information in accessible ways. However, most of misinformation on COVID-19 available in most of the websites, social media sites are increasing every day ${ }^{22}$.

The results support the need for continued highfrequency communication touch points with high-risk communities and populations through most frequently accessed sources for news and health information.

\section{Limitations}

The current study was limited to the pharmacy students and faculty's who have access to answer questions. This was a web based study and is not conducted face to face; hence the data may be less reliable. Therefore, further research should involve different community-population and when possible used a community-based studies design are recommended.

\section{Conclusion}

The finding of this study demonstrates an average knowledge regarding clinical aspects of COVID-19 among pharmacy students. This condition testifies the importance of increased public health information through trusted information channels and sources. In spite of the fact that there are certain limits, this study may early assist to develop action plans to educate the healthcare students. We recommend implementation of educational courses about the pandemic COVID-19 and provide accessible, true, updated and valid information.

\section{References}

1. World Health Organization. Corona virus Disease 2019 Situation Reports. 2020. https://www. who.int/ emergencies/diseases/novel-coronavirus-2019/ situation-

2. WHO. 2020a. Corona virus Disease 2019 (COVID-19) Situation Report - 46. 2020. https:// www.who.int/docs/default-source/coronaviruse/ situation-reports/20200306-sitrep- 46-covid-19.pdf? sfvrsn=96b04adf_2

3. WHO. 2020b. Pneumonia of Unknown Cause China. 2020. https://www.who.int/csr/ Asian Journal of Psychiatry 51 (2020) 102083 don/05-january-2020pneumonia-of-unkown-cause-china/en/

4. WHO. 2020c. Rolling Updates on Corona virus Disease (COVID-19). 2020. https:// www.who.int/ emergencies/diseases/novel-coronavirus-2019/ events-as-they-happen 
5. Cui J, Li F, Shi Z-L. Origin and evolution of pathogenic Corona viruses. Nat Rev Microbiol. 2019; 17:18192. PMid: 30531947 PMCid: PMC7097006. https:// doi.org/10.1038/s41579-018-0118-9

6. Li F. Structure, function and evolution of Corona virus spike proteins. Ann Rev Virol. 2016; 3:23761. PMid: 27578435 PMCid: PMC5457962. https:// doi.org/10.1146/annurev-virology-110615-042301

7. Suryaman GK, Soejoedono RD, Setiyono A, Poetri $\mathrm{ON}$, Handharyani E. Isolation and characterization of avian Corona virus from healthy Eclectus parrots (Eclectus roratus) from Indonesia. Vet World. 2019; 12:1797-805. PMid: 32009759 PMCid:PMC6925039. https://doi.org/10.14202/vetworld.2019.1797-1805

8. Zeng ZQ, Chen DH, Tan WP, Qiu SY, Xu D, Liang $\mathrm{HX}$, et al. Epidemiology and clinical characteristics of human Corona viruses OC43, 229E, NL63 and HKU1: A study of hospitalized children with acute respiratory tract infection in Guangzhou, China. Eur J Clin Microbiol Infect Dis. 2018; 37:363-9. PMid: 29214503 PMCid: PMC5780525. https://doi.org/10. 1007/s10096-017-3144-Z

9. Neher RA, Dyrdak R, Druelle V, Hodcroft EB, Albert J. Potential impact of seasonal forcing on a SARSCoV-2 pandemic. Swiss Med Wkly. 2020; 150:w20224. https://doi.org/10.4414/smw.2020.20224

10. Song Z, XuY, Bao L, Zhang L, Yu P, Qu Y, et al. From SARS to MERS, thrusting Corona viruses into the spotlight. Viruses. 2019; 11:59. PMid:306465 65 PMCid: PMC6357155.https://doi.org/10.3390/v11 010059

11. De Wit E, Van Doremalen N, Falzarano D, Munster VJ. SARS and MERS: Recent insights into emerging Corona viruses. Nat Rev Microbiol. 2016; 14:52334. PMid: 27344959 PMCid: PMC7097822. https:// doi.org/10.1038/nrmicro.2016.81

12. Hui DS. Epidemic and emerging Corona viruses (Severe acute respiratory syndrome and middle-east respiratory syndrome). Clin Chest Med. 2017; 38:7186. PMid: 28159163 PMCid: PMC7131795. https:// doi.org/10.1016/j.ccm.2016.11.007

13. WHO. WHO | Middle East Respiratory Syndrome Corona virus (MERS-CoV) - United Arab Emirates. Abu Dhabi: WHO. 2020.
14. Who.int. 2021. Public Health Surveillance For COVID-19: Interim Guidance. 2021 Jan. https:// www.who.int/publications/i/item/who-2019-nCoVsurveillanceguidance-2020.8

15. Centers for Disease Control and Prevention. 2021. Healthcare Workers. 2021 Jan. https://www.cdc.gov/ coronavirus/2019-ncov/hcp/index.html

16. Taghrir MH, Borazjani R, Shiraly R. COVID-19 and Iranian Medical Students; A survey on their related-knowledge, preventive behaviors and risk perception. Arch Iran Med. 2020; 23:249-54. PMid: 32271598. https://doi.org/10.34172/aim.2020.06

17. Jarab A, Al-Qerem W, Mukattash T, Al-Hajjeh D. Pharmacy and Pharm. D students' knowledge and information needs about COVID-19. Internatio nal Journal of Clinical Practice. 2020. https://doi.org/ 10.1111/ijcp. 13696

18. Mohsin SF, Agwan MA, Alsuwaydani ZA. Knowledge towards COVID-19 among healthcare students in the central region of Saudi Arabia: A cross-sectional observational study. Postgrad Med J. 2020; 0:1-4. PMid: 32759377. https://doi.org/10.11 36/postgradmedj-2020-138274

19. Chesser A, Ham AD, Woods NK. Assessment of COVID-19 knowledge among university students : Implications for Future Risk Communication Strategies. Health Education and Behavior. 2020; 47(4):540-3. PMid: 32460566. https://doi.org/ $10.1177 / 1090198120931420$

20. Song P, Karako T. COVID-19: Real-time dissemina tion of scientific information to fight a public health emergency of international concern. BioScience Tre nds.2020; 14(1):1-2.PMid: 32092748. https://doi.org /10.5582/bst.2020.01056

21. Nemati M, Ebrahimi B, Nemati F. Assessment of Iranian nurses' knowledge and anxiety toward COVID-19 during the current outbreak in Iran. Arch Clin Infect Dis. 2020; 15:e102848. https://doi.org/10. 5812/archcid.102848

22. Zhong BL, Luo W, Li HM, Zhang QQ, Liu XG, Li WT, Li Y. Knowledge, attitudes and practices towards COVID-19 among Chinese residents during the rapid rise period of the COVID-19 outbreak: A quick online cross-sectional survey. Int J Biol Sci. 2020; 16:174552. PMid: 32226294 PMCid: PMC7098034. https:// doi.org/10.7150/ijbs.45221 